\title{
Evaluation of Primary Prevention of Risk Behaviour in Preschool Education Institutions from the Perspective of Teachers
}

\author{
Vladimíra Kocourková, Jana Kantorová, Anna Šafránková
}

\begin{abstract}
The contribution presents the issue of factors influencing the level of primary prevention of risk behaviour in preschool education institutions, perceived also within the dimensions of school climate. It further presents the outcomes of a survey focused on evaluation of the level of primary prevention of risk behaviour from the perspective of kindergarten teachers (mainly women teachers) in the Czech Republic.
\end{abstract}

Key words: primary prevention, risk behaviour, kindergarten, preschool education, school climate, needs, kindergarten woman teacher/man teacher

\section{Abstrakt}

Příspěvek se zabývá problematikou faktorů ovlivňujících úroveň primární prevence rizikového chování v institucích předškolního vzdělávání, která je vnímána také v rozměrech školního klimatu. Dále uvádí výsledky průzkumu zaměřeného na hodnocení úrovně primární prevence rizikového chování z pohledu učitelů mateřských škol (zejména žen - učitelek) v České republice. 
Klíčová slova: primární prevence, rizikové chování, mateřská škola, předškolní vzdělávání, klima školy, potřeby, mateřská škola učitelka/učitel.

\section{Introduction}

The following contribution pays general attention first to selected factors that are presumed to have influence on the level (quality) of primary prevention of risk behaviour in preschool education institutions, or namely kindergartens in the Czech Republic. It emphasizes the factor of teacher (woman teacher) and deals with teachers' evaluation of primary prevention of risk behavior at their workplaces. The issue of primary prevention in preschool education institutions has been dealt with for a long time, and the area of determining factors is perceived as very important. Now the project IGA_PdF_2014018 titled "Kindergarten School Climate Respecting the Needs of a Child as a Protective Factor of Primary Prevention of Risk Behaviour" is carried out; the discussed area is significantly reflected in it. The project data are collected by means of both the qualitative and quantitative research strategies. What is accentuated is kindergarten school climate and respect for the needs of children attending kindergartens; the personality of a teacher plays the key role in both the cases. We would like to present the issue not only in the framework of theoretical thinking but mainly from the viewpoint of the data of our realized project, not published so far; these have become one of the starting points of the current project.

\section{Primary prevention of risk behaviour}

Any conceivable intervention, in the sense starting with preventing something and early intervention to therapeutic intervention up to relapse prevention, can be called prevention. Primary, secondary and tertiary prevention is distinguished on the basic level in the contemporary practice. These terms were introduced by G. Caplan in his work "Principles of Preventive Psychiatry" (1964). The level of primary prevention is carried out within preschool education; i.e. the one that is focused on the entire population, without examining the level of danger. Primary prevention is divided into nonspecific and specific prevention. Specific prevention focuses its attention to particular groups of risk behaviour, tries to reduce the influence of risk factors in narrowly defined phenomena (e.g. aggressive behaviour). (Scheitenhauer, H., Hayer, T., Niebank, K., 2008) Nonspecific primary prevention is focused on general circumstances of the development of an individual's personality, including all activities supporting healthy life style and acquisition of positive social conduct by means of meaningful use and organization of spare time, e.g. hobbies, sports and spare time activities and other programmes leading 
to compliance with certain social rules, healthy development of personality, responsibility for oneself and one's conduct. (Metodické doporučení k primární prevenci rizikového chování u dětí, žáků a studentů ve školách a školských zařizeních, č.j. 21291/2010-28). The dominant position at kindergarten is occupied by nonspecific prevention due to its character. (Kocourková, V., Šafránková, A., 2012)

Risk behaviour is understood as ways of uncertain conduct having the potential of harms relating to one's own life or environment (living conditions in society) (Raithel, J., 2011). Thus the risks for individuals (social, health, economic etc.) are increasing.

\section{Presumed factors influencing the level of primary prevention of risk behaviour at kindergarten}

Factors that can influence the level (qualitative side) of primary prevention of risk behaviour at kindergarten are of multidimensional character. Basically, it is possible to consider four main areas of agents; the common factor of these is school climate in its particular dimensions (see chart 1).

The personal factors include personalities of particular agents - internal school partners. An important role is played by the personality of a kindergarten teacher (temperament, character, duration of practice, gender). According to Bessoth (1989), the social dimension of school climate is determined by persons or groups of persons that are in direct or indirect contact with the school. The psychosocial factors include relationships among particular participants - internal and external school partners, team of teachers, quality of management, parents' participation etc. The quality of education is based on competences of a kindergarten teacher, the way of pedagogical thinking etc. According to Bessoth (1989), the social dimension of school climate is related to behaviour or patterns of behaviour of persons or groups of persons at school; also persons or groups of persons that are in direct or indirect contact with the school. According to our opinion, the material factors include both the generally social and political society reflected in the education process and namely the character and situation of the locality (village, town, excluded localities etc.). Further particularly the character of a school building (arrangement of furniture, size of the building and rooms) and the character of a kindergarten (e.g. arrangement of the furniture and its suitability for children; toys quantity, selection). According to Bessoth (1989), the ecological dimension of school climate includes physical and material aspects of school. Only the level of organization of the running of a kindergarten will be mentioned in relation to organization of a kindergarten; we would like to emphasize not only organization of work in a class but also the number of children in a class. According to Bessoth (1989), the cultural dimension of school climate is determined by value patterns, norms, religion, expert competences and significance of all persons at school. 


\section{Chart 1}

Selected factors that can influence the level of primary prevention of risk behaviour at kindergarten

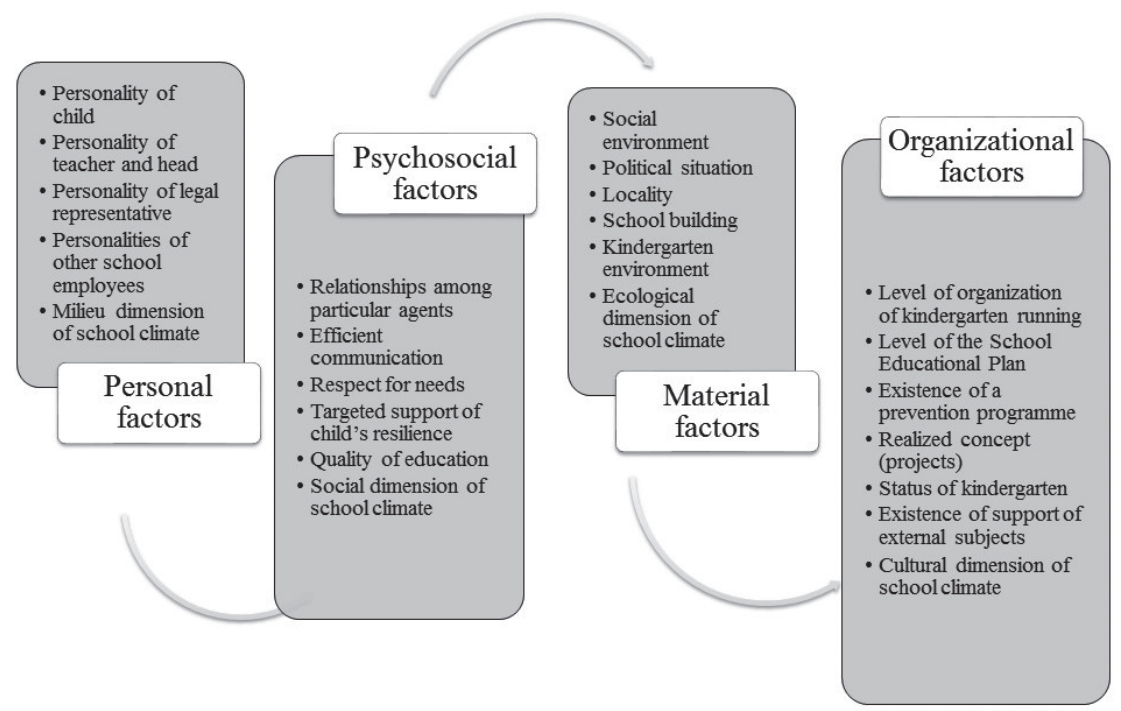

[Reference: Smolíková, K. et al., 2004; Essa, E., 2011; IGA PdF_2012_047 “Pedagogical Aspects of Prevention and Resilience in the Preschool Educational Institution" (Kocourková, V. Šafránková, A., 2012); IGA_PdF_2014018“Kindergarten School Climate Respecting the Needs of a Child as a Protective Factor of Primary Prevention of Risk Behavior" (Kocourková, V., Kantorová, J., Šafránková, A., 2014); Bessoth, R., 1989.]

All the factors are interconnected and blended. Nevertheless, what should be pointed out is the role of personal factors and psychosocial factors very closely related to them. It is namely the personality of a teacher that can actively intervene and change the prevailing majority of other conditions (factors), and thus it plays the key role. This is why the personality of a teacher is one of the "areas" of our surveys. The survey that is to be presented here was focused on teachers' evaluation of primary prevention of risk behaviour at schools (their own workplaces) what can reflect the level of the given prevention to a certain extent too. 


\section{Evaluation of primary prevention of risk behaviour from the perspective of kindergarten teachers - a survey}

The survey, focused on evaluation of primary prevention of risk behaviour from the perspective of kindergarten teachers, was carried out at the end of 2012 and the beginning of 2013. It was part of the project IGA PdF_2012_047 “Pedagogical Aspects of Prevention and Resilience in the Preschool Educational Institution" (Kocourková, V. Šafránková, A.). The part that was carried out by means of quantitative design gave birth to a research tool consisting of typical questionnaire items, items of the scale type and Q-methodology. The entire research tool was transformed into the electronic form.

Some of the scale-type items ( 14 out of the total number of 38 items) were aimed at evaluation of the level of prevention of risk behaviour by kindergarten teachers (some could have the function of kindergarten head at the same time). The outcomes of this part are to be published here.

The research tool was distributed via email to kindergarten heads asking them to forward it to teachers of the kindergartens. Of course, this way influenced returnability of the questionnaires. The questionnaires were sent to 4,175 email addresses; unfortunately some of them turned out to be defunct. The total of 888 questionnaires were returned; still, some had to be rejected, and thus 868 questionnaires were used for further processing. It means returnability was only around $20 \%$.

The respondents evaluated prevention of risk behaviour at their schools in the total of 14 items (5-point scales) of the questionnaire:

- Cooperation of the Pedagogical-Psychological Counselling Centre on the issues of prevention of risk behaviour is optimum at the kindergarten where you work.

- Communication with children's families regarding prevention of risk behaviour is optimum at the kindergarten where you work.

- The objective of prevention of risk behaviour is set absolutely specifically and in writing at the kindergarten where you work.

- The content of prevention of risk behaviour at the kindergarten where you work is based on a clearly and specifically defined objective.

- The methods of prevention of risk behaviour at the kindergarten where you work are based on a defined objective and content.

- Parents of all the children are at least once a month informed of activities of prevention of risk behaviour at the kindergarten where you work.

- Parents of all the children actively participate in prevention of risk behaviour at the kindergarten where you work. 
- You implement prevention of risk behaviour into your teaching activities by intent.

- A targeted analysis of problems occurring in the particular locality is carried out at the kindergarten where you work.

- A targeted analysis of internal resources is carried out at the kindergarten where you work.

- Regular (at least once in six months) diagnostics of children's knowledge and abilities in relation to prevention of risk behaviour is carried out at the kindergarten where you work.

- Regular (at least once a year) evaluation of preventive influence based on the set specific objectives is carried out at the kindergarten where you work.

- A targeted analysis of children's needs is carried out at the kindergarten where you work.

- A targeted analysis of protective and risk factors influencing particular children in relation to prevention of risk behaviour is carried out at the kindergarten where you work.

Value 1 was for the best evaluation and value 5 the worst one in the used scales (I absolutely agree, I rather agree, I do not have a clear opinion, I rather disagree, I absolutely disagree). It is the average number of points given by the respondents in the said 14 scales that can be one of the indicators of the level of prevention of risk behaviour.

Hypothetically, a difference was presumed in evaluation of the level of prevention of risk behaviour depending on:

- the duration of the respondents' teaching practice,

- the region,

- the founder (state, private kindergarten),

- the school status (independent school, together with an elementary school),

- the school locality (town, village),

- the respondents' function in the kindergarten (head, teacher),

- the achieved level of education,

- the existence of a prevention programme,

- the size of the kindergarten (up to 50 children, over 50 children). 


\section{Outcomes of the survey}

\section{The duration of teaching practice}

The respondents were divided into two categories according to the duration of their teaching practice: category 1 (practice up to 10 years), category 2 (practice over 10 years).

Table 1

Average evaluation of the level of prevention of risk behaviour vs. duration of the respondents' teaching practice $(P x)$

\begin{tabular}{|l|l|l|c|c|c|c|c|}
\hline \multirow{2}{*}{$\begin{array}{l}\text { Duration } \\
\text { of teaching practice }\end{array}$} & \multicolumn{2}{|l|}{$\begin{array}{l}\text { t-tests; grouped: Px: } 1=\text { up to 10; } 2=11 \text { and over (DATA_korig_trans) } \\
\text { Group over 10 } \\
\text { Group up to 10 years }\end{array}$} \\
\cline { 2 - 8 } & $\begin{array}{l}\text { Average } \\
\text { over 10 }\end{array}$ & $\begin{array}{c}\text { Average } \\
\text { up to 10 }\end{array}$ & $\mathrm{t}$ & sv & p & $\begin{array}{c}\text { Number } \\
\text { of valid 2 }\end{array}$ & $\begin{array}{c}\text { Number } \\
\text { of valid 1 }\end{array}$ \\
\hline $\begin{array}{l}\text { Average evaluation } \\
\text { of the level of prevention }\end{array}$ & 2.21 & 2.46 & -4.165 & 866 & 0.000034 & 711 & 157 \\
\hline
\end{tabular}

A statistically significant difference (signification $p=0.000034$ ) was confirmed between the groups of the respondents according to the duration of their practice. The group of respondents with the duration of practice over 10 years evaluated the level of prevention significantly better than the group of practice up to 10 years. It is possible to presume an influence of one's experience and its reflection in evaluation and maybe even implementation of primary prevention of risk behaviour.

\section{Regions of the Czech Republic}

Table 2

Average evaluation of the level of prevention in particular regions of the Czech Republic

\begin{tabular}{|c|c|c|c|}
\hline \multirow{2}{*}{$\begin{array}{l}\text { Regions } \\
\text { of the Czech Republic }\end{array}$} & \multicolumn{3}{|l|}{$\begin{array}{l}\text { Analytic table of descriptive statistics (DATA__korig_trans) } \\
\mathrm{N}=868\end{array}$} \\
\hline & Average evaluation of the level of prevention & $\mathrm{n}$ & Standard deviation \\
\hline Olomouc & 2.23 & 158 & 0.724021 \\
\hline Hradec Králové & 2.24 & 21 & 0.477354 \\
\hline Central Bohemian & 2.20 & 28 & 0.584847 \\
\hline Central Bohemian & 2.28 & 45 & 0.700417 \\
\hline Plzeň & 2.21 & 83 & 0.652697 \\
\hline Capital of Prague & 2.37 & 51 & 0.664377 \\
\hline South Moravian & 2.21 & 101 & 0.639551 \\
\hline Liberec & 2.24 & 67 & 0.713643 \\
\hline Moravian Silesian & 2.32 & 30 & 0.772888 \\
\hline
\end{tabular}




\begin{tabular}{|l|c|c|c|c|}
\hline \multirow{2}{*}{$\begin{array}{l}\text { Regions } \\
\text { of the Czech Republic }\end{array}$} & \multicolumn{4}{|l|}{$\begin{array}{l}\text { Analytic table of descriptive statistics (DATA_korig_trans) } \\
\mathrm{N}=868\end{array}$} \\
\cline { 2 - 5 } & & Average evaluation of the level of prevention & $\mathbf{n}$ & Standard deviation \\
\hline Vysočina & & 2.32 & 95 & 0.753546 \\
\hline Zlín & & 2.17 & 62 & 0.646772 \\
\hline Pardubice & & 2.26 & 70 & 0.631841 \\
\hline Karlovy Vary & & 2.377 & 31 & 0.652101 \\
\hline South Bohemian & $\Sigma$ & 2.29 & 26 & 0.717799 \\
\hline & 2.25 & 868 & 0.680369 \\
\hline
\end{tabular}

Differences between the averages in particular regions of the Czech Republic were not statistically significant (signification $p=0.950245$ ).

\section{State/private kindergarten}

Table 3

Average evaluation of the level of prevention of risk behaviour vs. state/private kindergarten

\begin{tabular}{|c|c|c|c|c|c|c|c|}
\hline \multirow{2}{*}{$\begin{array}{l}\text { State/private } \\
\text { kindergarten }\end{array}$} & \multicolumn{7}{|c|}{$\begin{array}{l}\text { t-tests; grouped: pol4 (DATA__korig_trans) } \\
\text { Group state } \\
\text { Group private }\end{array}$} \\
\hline & $\begin{array}{c}\text { Average } \\
\text { state }\end{array}$ & $\begin{array}{l}\text { Average } \\
\text { private }\end{array}$ & $t$ & SV & $p$ & $\begin{array}{l}\text { Number of } \\
\text { valid state }\end{array}$ & $\begin{array}{c}\text { Number of } \\
\text { valid private }\end{array}$ \\
\hline $\begin{array}{l}\text { Average evaluation } \\
\text { of the level of prevention }\end{array}$ & 2.25 & 2.50 & -1.568 & 866 & 0.1171 & 849 & 19 \\
\hline
\end{tabular}

No statistically significant difference was proved (signification $p=0.1171$ ).

\section{Independent kindergarten/kindergarten together with an elementary school}

Table 4

Average evaluation of the level of prevention of risk behaviour vs. independent kindergarten/kindergarten together with an elementary school (pol5)

\begin{tabular}{|l|c|c|c|c|c|c|c|}
\hline \multirow{2}{*}{$\begin{array}{l}\text { Independent/together } \\
\text { with ES }\end{array}$} & \multicolumn{6}{|l|}{$\begin{array}{l}\text { t-tests; grouped: pol5 (DATA_korig_trans) } \\
\text { Group independent } \\
\text { Group together with ES }\end{array}$} \\
\cline { 2 - 8 } & $\begin{array}{c}\text { Average } \\
\text { independent }\end{array}$ & $\begin{array}{c}\text { Average } \\
\text { together } \\
\text { with ES }\end{array}$ & t & SV & p & $\begin{array}{c}\text { Number } \\
\text { of valid } \\
\text { independent }\end{array}$ & $\begin{array}{c}\text { Number } \\
\text { of valid together } \\
\text { with ES }\end{array}$ \\
\hline $\begin{array}{l}\text { Average evaluation } \\
\text { of the level of prevention }\end{array}$ & 2.23 & 2.30 & -1.4901 & 866 & 0.136548 & 553 & 315 \\
\hline
\end{tabular}


No statistically significant difference was proved (signification $p=0.136548$ ).

\section{School locality}

Table 5

Average evaluation of the level of prevention of risk behaviour vs. village/town

\begin{tabular}{|l|c|c|c|c|c|c|c|}
\hline \multirow{8}{*}{ School locality } & \multicolumn{2}{|l|}{$\begin{array}{l}\text { t-tests; grouped: pol6 (DATA_korig_trans) } \\
\text { Group town } \\
\text { Group village }\end{array}$} \\
\cline { 2 - 7 } & $\begin{array}{c}\text { Average } \\
\text { town }\end{array}$ & $\begin{array}{c}\text { Average } \\
\text { village }\end{array}$ & t & SV & p & $\begin{array}{c}\text { Number } \\
\text { of valid town }\end{array}$ & $\begin{array}{c}\text { Number } \\
\text { of valid village }\end{array}$ \\
\hline $\begin{array}{l}\text { Average evaluation } \\
\text { of the level of prevention }\end{array}$ & 2.24 & 2.28 & -0.80494 & 866 & $\mathbf{0 . 4 2 1 0 7}$ & 514 & 354 \\
\hline
\end{tabular}

No statistically significant difference was proved (signification 0.42107).

\section{Function at the kindergarten}

Table 6

Average evaluation of the level of prevention of risk behaviour vs. (head + teacher)/teacher

\begin{tabular}{|l|c|c|c|c|c|c|c|}
\hline \multirow{2}{*}{ (Head + teacher)/teacher } & \multicolumn{2}{|l|}{$\begin{array}{l}\text { t-tests; grouped: pol7 (DATA_korig_trans) } \\
\text { Group 1: head + teacher } \\
\text { Group 2: teacher }\end{array}$} \\
\cline { 2 - 8 } & $\begin{array}{c}\text { Average } \\
\text { head + teacher }\end{array}$ & $\begin{array}{c}\text { Average } \\
\text { teacher }\end{array}$ & t & sv & p & $\begin{array}{c}\text { Number } \\
\text { of valid } \\
\text { head + teacher }\end{array}$ & $\begin{array}{c}\text { Number } \\
\text { of valid } \\
\text { teacher }\end{array}$ \\
\hline $\begin{array}{l}\text { Average evaluation } \\
\text { of the level of prevention }\end{array}$ & 2.17 & 2.38 & -4.08374 & 672 & 0.000050 & 301 & 373 \\
\hline
\end{tabular}

A statistically significant difference was proved between evaluation of both the groups of respondents (signification $p=0.000050$ ). The heads evaluated the level of prevention significantly better. Again, the influence of experience can be taken into consideration; still, it is possible to consider a pitfall when a kindergarten head tries to present the situation in a better light than in reality. 


\section{Achieved education}

Table 7

Average evaluation of the level of prevention of risk behaviour vs. education corresponding with university/corresponding with higher education

\begin{tabular}{|l|c|c|c|c|c|c|c|}
\hline \multirow{2}{*}{ Variable } & \multicolumn{2}{|l|}{$\begin{array}{l}\text { t-tests; grouped: pol8 (DATA_korig_trans) } \\
\text { Group 1: corrU } \\
\text { Group 2: CORRhe }\end{array}$} \\
\cline { 2 - 8 } & $\begin{array}{c}\text { Average } \\
\text { corrU }\end{array}$ & $\begin{array}{c}\text { Average } \\
\text { corrHE }\end{array}$ & $\mathrm{t}$ & sv & $\mathrm{p}$ & $\begin{array}{c}\text { Number of } \\
\text { valid corrU }\end{array}$ & $\begin{array}{c}\text { Number of } \\
\text { valid corrHE }\end{array}$ \\
\hline $\begin{array}{l}\text { Average evaluation } \\
\text { of the level of prevention }\end{array}$ & 2.28 & 2.28 & 0.004554 & 385 & 0.996369 & 332 & 55 \\
\hline
\end{tabular}

No statistically significant difference was proved between evaluation by both the groups of respondents (signification $p=0.996369$ ).

Table 8

Average evaluation of the level of prevention of risk behaviour vs. education corresponding with university/corresponding with secondary education

\begin{tabular}{|l|c|c|c|c|c|c|c|}
\hline \multirow{2}{*}{ Variable } & \multicolumn{2}{|l|}{$\begin{array}{l}\text { t-tests; grouped: pol8 (DATA_korig_trans) } \\
\text { Group 1: corrU } \\
\text { Group 2: corrSE }\end{array}$} \\
\cline { 2 - 8 } & $\begin{array}{c}\text { Average } \\
\text { corrU }\end{array}$ & $\begin{array}{c}\text { Average } \\
\text { corrSE }\end{array}$ & $\mathrm{t}$ & sv & $\mathbf{p}$ & $\begin{array}{c}\text { Number of } \\
\text { valid corrU }\end{array}$ & $\begin{array}{c}\text { Number of } \\
\text { valid corrSE }\end{array}$ \\
\hline $\begin{array}{l}\text { Average evaluation } \\
\text { of the level of prevention }\end{array}$ & 2.28 & 2.22 & 1.259951 & 791 & 0.208059 & 332 & 461 \\
\hline
\end{tabular}

No statistically significant difference was proved between evaluation by both the groups of respondents (signification $p=0.208059$ )

Table 9

Average evaluation of the level of prevention of risk behaviour vs. education corresponding with higher education/corresponding with secondary education

\begin{tabular}{|l|c|c|c|c|c|c|c|}
\hline \multirow{2}{*}{ Variable } & \multicolumn{2}{|l|}{$\begin{array}{l}\text { t-tests; grouped: pol8 (DATA_korig_trans) } \\
\text { Group 1: corrHE } \\
\text { Group 2: corrSE }\end{array}$} \\
\cline { 2 - 8 } & $\begin{array}{c}\text { Average } \\
\text { corrHE }\end{array}$ & corrSE & $\mathrm{t}$ & sV & p & $\begin{array}{c}\text { Number of } \\
\text { valid corrHE }\end{array}$ & $\begin{array}{c}\text { Number of } \\
\text { valid corrSE }\end{array}$ \\
\hline $\begin{array}{l}\text { Average evaluation } \\
\text { of the level of prevention }\end{array}$ & 2.28 & 2.22 & 0.634222 & 514 & 0.526218 & 55 & 461 \\
\hline
\end{tabular}


No statistically significant difference was proved between evaluation of both the groups of respondents (signification $p=0.526218$ )

\section{Existence of a prevention programme}

Table 10

Average evaluation of the level of prevention of risk behaviour vs. existence of a prevention programme

\begin{tabular}{|l|c|c|c|c|c|c|c|}
\hline \multirow{2}{*}{$\begin{array}{l}\text { t-tests; grouped: pol9 (DATA_korig_trans) } \\
\text { Group not having elaborated a prevention programme } \\
\text { Group having elaborated a prevention programme } \\
\text { existing/not existing }\end{array}$} & $\begin{array}{c}\text { Average } \\
\text { not having }\end{array}$ & $\begin{array}{c}\text { Average } \\
\text { having }\end{array}$ & $\mathrm{t}$ & sv & $\mathrm{p}$ & $\begin{array}{c}\text { Number of valid } \\
\text { not having }\end{array}$ & $\begin{array}{c}\text { Number of } \\
\text { valid having }\end{array}$ \\
\hline $\begin{array}{l}\text { Average evaluation } \\
\text { of the level of prevention }\end{array}$ & 2.47 & 2.01 & 10.64832 & 866 & 0.000000 & 455 & 413 \\
\hline
\end{tabular}

The existence of a statistically significant difference was proved between the groups (signification $p<0.0000001$ ). Thus it is possible to say that teachers from schools where a prevention programme is elaborated evaluate the level of prevention of risk behaviour better. It is necessary to be aware of the fact that most schools that stated having elaborated a prevention programme are kindergartens running together with an elementary school. Independent kindergartens having a prevention programme are rather exceptions.

\section{Size of the kindergarten}

Table 11

Average evaluation of the level prevention of risk behaviour vs. size of the kindergarten

\begin{tabular}{|l|c|c|c|c|c|c|c|}
\hline \multicolumn{1}{|l|}{$\begin{array}{l}\text { t-tests; grouped: Size_sch: 1=to 50; 2=0ver 50 (DATA_korig_trans) } \\
\text { Group over 50 } \\
\text { Group to } 50\end{array}$} & $\begin{array}{c}\text { Average } \\
\text { Size of the kindergarten }\end{array}$ & t & sv & p & $\begin{array}{c}\text { Number of } \\
\text { valid over } 50\end{array}$ & $\begin{array}{c}\text { Number of } \\
\text { valid to } 50\end{array}$ \\
\hline $\begin{array}{l}\text { Average } 50 \\
\text { Average evaluation } \\
\text { of the level of prevention }\end{array}$ & 2.25 & 2.25 & 0.049450 & 866 & 0.960572 & 529 & 339 \\
\hline
\end{tabular}

No statistically significant difference was proved (signification $p=0.960572$ ). 


\section{Conclusion}

The presented contribution outlined possible factors influencing the level of primary prevention of risk behaviour while the personality of a teacher (woman teacher) was emphasized. It also dealt with teachers' evaluation of the current situation in the field of primary prevention at their own workplaces. The presented survey outcomes showed statistically significant differences in evaluation of primary prevention from the perspective of duration of the respondents' practice, the perspective of their functions in kindergartens and also the perspective of existence of a prevention programme at the schools; these are considered to be significant findings. The schools having elaborated an independent prevention programme evaluate prevention at the school better than the schools not having elaborated an independent prevention programme. It is possible to presume that it is caused by targeted and conscious activity in this area. Still, kindergartens have no duty to create an independent prevention programme. It is presumed that prevention of risk behaviour in kindergartens is carried out by means of quality elaboration and especially realization of school education programme based on the Framework Education Programme for preschool education.

Generally, it is possible to sum up that the issue of primary prevention of risk behaviour is still very topical, and its importance is rising. When taking account of the principles of primary prevention, namely its early beginning, it is necessary to pay attention to this issue within activities of preschool educations (specifically kindergartens), to support teachers' competencies in practice and to consciously work with all the factors that can influence the level of primary prevention at kindergartens. The issue is also topical not only from the viewpoint of practice but also from the viewpoint of theory and research (pedagogical research, or in combination with psychological research); the area of the factors influencing the level of prevention is only one of the partial options of research - the field of possible research is much wider from the general perspective and not sufficiently used from our perspective.

\section{References}

Bessoth, R. (1989). Verbesserung des Unterrichtsklimas. Neuwied: Luchterhand.

Caplan, G. (1964). Principles of psychiatry. New York: Basic Books.

Essa, E. (2011). Jak pomoci dítěti. Metody zvládání problémů dětí v předškolní výchově. Brno: Computer Press.

Kocourková, V., \& Šafránková, A. (2012). Prevence rizikového chování jako nutná součást předškolního vzdělávání. GRANT journal, 2, pp. 45-47.

MŠMT. Metodické doporučení k primární prevenci rizikového chování u dětí, žáků a studentů ve školách a školských zařízeních, č.j. 21291/2010-28.

Raithel, J. (2011). Jugendliches Risikoverhalten: Eine Einführung. Wiesbaden: VS, Verlag für Sozialwisseschaften. 
Scheithauer, H., Hayer, T., \& Niebank, K. (2008). Problemverhalten und Gewalt im Jugendalter: Erscheinungsformen, Entstehungsbedingungen, Prävention und Intervention. Stuttgart: Kohlhammer. Smolíková, K. et al. (2006). Rámcový vzdělávací program pro předškolní vzdělávání. Praha: VúP.

\section{Contact:}

PhDr. Vladimíra Kocourková, Ph.D.

PhDr. Jana Kantorová, Ph.D.

Mgr. Anna Šafránková

Institute of Education and Social Sciences

Faculty of Education, Palacký University Olomouc

Žižkovo nám. 5, 77140 Olomouc, CZ

Tel: 00420-585 635874

E-mails: vladimira.kocourkova@upol.cz; jana.kantorova@upol.cz; anna.safrankova@upol.cz 